\title{
A Functional Henipavirus Envelope Glycoprotein Pseudotyped Lentivirus Assay System
}

\author{
Dimple Khetawat, Christopher C Broder
}

\begin{abstract}
Background: Hendra virus ( $\mathrm{HeV}$ ) and Nipah virus (NiV) are newly emerged zoonotic paramyxoviruses discovered during outbreaks in Queensland, Australia in 1994 and peninsular Malaysia in 1998/9 respectively and classified within the new Henipavirus genus. Both viruses can infect a broad range of mammalian species causing severe and often-lethal disease in humans and animals, and repeated outbreaks continue to occur. Extensive laboratory studies on the host cell infection stage of $\mathrm{HeV}$ and NiV and the roles of their envelope glycoproteins have been hampered by their highly pathogenic nature and restriction to biosafety level-4 (BSL-4) containment. To circumvent this problem, we have developed a henipavirus envelope glycoprotein pseudotyped lentivirus assay system using either a luciferase gene or green fluorescent protein (GFP) gene encoding human immunodeficiency virus type-1 (HIV-1) genome in conjunction with the HeV and NiV fusion (F) and attachment (G) glycoproteins.
\end{abstract}

Results: Functional retrovirus particles pseudotyped with henipavirus $F$ and $G$ glycoproteins displayed proper target cell tropism and entry and infection was dependent on the presence of the HeV and NiV receptors ephrinB2 or B3 on target cells. The functional specificity of the assay was confirmed by the lack of reporter-gene signals when particles bearing either only the F or only G glycoprotein were prepared and assayed. Virus entry could be specifically blocked when infection was carried out in the presence of a fusion inhibiting C-terminal heptad (HR-2) peptide, a well-characterized, cross-reactive, neutralizing human mAb specific for the henipavirus G glycoprotein, and soluble ephrinB2 and B3 receptors. In addition, the utility of the assay was also demonstrated by an examination of the influence of the cytoplasmic tail of $\mathrm{F}$ in its fusion activity and incorporation into pseudotyped virus particles by generating and testing a panel of truncation mutants of NiV and HeV F.

Conclusions: Together, these results demonstrate that a specific henipavirus entry assay has been developed using NiV or HeV F and G glycoprotein pseudotyped reporter-gene encoding retrovirus particles. This assay can be conducted safely under BSL-2 conditions and will be a useful tool for measuring henipavirus entry and studying $F$ and $\mathrm{G}$ glycoprotein function in the context of virus entry, as well as in assaying and characterizing neutralizing antibodies and virus entry inhibitors.

\section{Background}

Hendra virus $(\mathrm{HeV})$ emerged in 1994 in two separate outbreaks of severe respiratory disease in horses with subsequent transmission to humans resulting from close contact with infected horses. Nipah virus (NiV) was later determined to be the causative agent of a major outbreak of disease in pigs in 1998-99 along with cases of febrile encephalitis among people in Malaysia and Singapore who were in close contact exposure to infected pigs (reviewed in $[1,2]$ ). Phylogenetic analysis

\footnotetext{
* Correspondence: cbroder@usuhs.mil

Department of Microbiology and Immunology, Uniformed Services University, Bethesda, Maryland 20814, USA
}

revealed that $\mathrm{HeV}$ and $\mathrm{NiV}$ are distinct members of the Paramyxoviridae $[3,4]$ and are now the prototypic members of the new genus Henipavirus within the paramyxovirus family [4]. Pteropid fruit bats, commonly known as flying foxes in the family Pteropodidae, are the principal natural reservoirs for both $\mathrm{NiV}$ and $\mathrm{HeV}$ (reviewed in [2]) however recent evidence of henipavirus infection in a wider range of both frugivorous and insectivorous bats has been reported $[5,6]$.

Since their identification, both $\mathrm{HeV}$ and $\mathrm{NiV}$ have caused repeated spillover events. There have been 14 recognized occurrences of $\mathrm{HeV}$ in Australia since 1994 with at least one occurrence per year since 2006, the 
most recent in May 2010. Every outbreak of $\mathrm{HeV}$ has involved horses as the initial infected host, causing lethal respiratory disease and encephalitis, along with a total of seven human cases arising from exposure to infected horses, among which four have been fatal and the most recent in 2009 (reviewed in [2]) [7-9]. By comparison there have been more than a dozen occurrences of NiV emergence since its initial recognition, most appearing in Bangladesh and India (reviewed [2]) and the most recent in March 2008 [10] and January 2010 [11]. Among these spillover events of NiV the human mortality rate has been higher $(\sim 75 \%)$ along with evidence of person-to-person transmission $[12,13]$ and direct transmission of virus from flying foxes to humans via contaminated food [14].

In contrast to other paramyxoviruses, $\mathrm{NiV}$ and $\mathrm{HeV}$ exhibit an extremely broad host tropism and in addition to bats, horses, pigs and humans, natural and/or experimental infections have also been reported in cats, dogs, guinea pigs, hamsters (reviewed in [2]), ferrets [15] and some nonhuman primates, the squirrel monkey [16] and the African green monkey $[17,18]$. In those hosts susceptible to henipavirus-induced pathology, the disease is characterized as a widespread multisystemic vasculitis, with virus replication and associated pathology in highly vascularized tissues including the lung, spleen and brain $[2,19]$. Both the broad host and tissue tropisms exhibited by $\mathrm{NiV}$ and $\mathrm{HeV}$ can for the most part be explained by the highly conserved and broadly expressed nature of the receptors the henipaviruses employ, the ephrinB2 and B3 ligands [20-23] which are members of a large family of important signaling proteins involved in cellcell interactions (reviewed in [24,25]).

$\mathrm{NiV}$ and $\mathrm{HeV}$ possess two envelope glycoproteins anchored within the viral membrane, a trimeric fusion (F) and a tetrameric attachment (G) glycoprotein (reviewed in [26]). The F glycoprotein is initially synthesized as a precursor $F_{0}$ which is cleaved into the disulfide-linked $F_{1}$ and $F_{2}$ subunits by cathepsin $L$ within the host cell [27]. The G glycoprotein consists of a stalk domain and globular head and G monomers form disulfide-linked dimers that associate in pairs forming tetramers [28]. The $F$ and $G$ oligomers associate within the membrane and $G$ is responsible for engaging receptors, which in turn triggers F-mediated membrane fusion (reviewed in [26]). The F and G glycoproteins of NiV and $\mathrm{HeV}$ share $~ 88 \%$ and $83 \%$ amino acid identity and both $\mathrm{NiV}$ and $\mathrm{HeV}$ can elicit cross-reactive anti-envelope glycoprotein antibody responses [29]. It has also been demonstrated that $\mathrm{F}$ and $\mathrm{G}$ of $\mathrm{NiV}$ and $\mathrm{HeV}$ can efficiently complement each other in a heterotypic manner in cell-fusion assays [30]. The henipavirus F and G glycoproteins share many of the general structural features found in the envelope glycoproteins of other paramyxoviruses, and recently the structure of both receptor-bound and unbound forms of the globular head domain of $\mathrm{NiV} G$ have been reported [31,32].

Because of their highly pathogenic nature and lack of approved vaccines or therapeutics, $\mathrm{HeV}$ and $\mathrm{NiV}$ are classified as biological safety level-4 (BSL-4) select agents by the Centers for Disease Control and Prevention (CDC) and as priority pathogens by the National Institute of Allergy and Infectious Diseases (NIAID), having the potential to cause significant morbidity and mortality in humans and major economic and public health impacts (reviewed [1]). These restrictions have somewhat limited detailed studies on virus entry and their envelope glycoprotein functions in the context of a viral particle. To circumvent these restrictions, virus pseudotyping systems have been examined, where the envelope glycoproteins from one virus are incorporated into the progeny virions of another that lacks its own envelope glycoprotein(s), effectively changing the host range and tropism of the virus. For example, the $\mathrm{F}$ and $\mathrm{G}$ envelope glycoproteins of NiV have been successfully incorporated into recombinant vesicular stomatitis virus (VSV) lacking VSV G glycoprotein (VSV- $\Delta \mathrm{G}$ ) and encoding green fluorescent protein (GFP) [21,33]. Other widely employed viral pseudotyping systems are those based on retroviral vectors, and lentiviral vectors have emerged as promising tools for a variety gene-delivery studies and can efficiently transduce proliferating as well as quiescent cells (reviewed in [34]).

Virus pseudotyping systems have been useful for the study of otherwise highly pathogenic viral agents such as Ebola and Marburg viruses, severe acute respiratory syndrome (SARS) coronavirus (SARS-CoV) and influenza virus [35-37]. Here, building on the initial findings of Kobayashi et al., [38], who first demonstrated that simian immunodeficiency virus from African green monkey (SIVagm) could be functionally pseudotyped with the $\mathrm{F}$ and hemagglutinin-neuraminidase $(\mathrm{HN})$ glycoproteins of Sendai virus $(\mathrm{SeV})$, we demonstrate for the first time that the $\mathrm{F}$ and $\mathrm{G}$ envelope glycoproteins of $\mathrm{NiV}$ and $\mathrm{HeV}$, a cellular protein receptor using paramyxovirus, can also be functionally pseudotyped into lentivirus particles using either a luciferase or GFP reporter gene encoding HIV-1 genome. These HIV-1 based, henipavirus glycoprotein pseudotyped particles exhibited the same cellular tropism characteristics as authentic $\mathrm{NiV}$ and $\mathrm{HeV}$, and virus entry was specifically inhibited by antiviral agents that target the henipaviruses. The pseudotyped particles could be readily concentrated by ultracentrifugation without any loss of infectivity, and using this system we also examined the incorporation of $\mathrm{F}$ and $\mathrm{G}$ glycoproteins into virions, and explored the infectivity and pseudotyping efficiency of cytoplasmic tail truncated versions of F. This lentivirus- 
based henipavirus glycoprotein pseudotyped particle infection assay can also be conducted safely under BSL-2 conditions and will be a useful tool for measuring henipavirus entry and for studying $\mathrm{F}$ and $\mathrm{G}$ glycoprotein function in the context of virus particle entry, as well as in assaying and characterizing neutralizing antibodies and virus entry inhibitors.

\section{Results}

\section{Henipavirus $\mathrm{F}$ and $\mathrm{G}$ envelope glycoprotein pseudotyped lentivirus particles}

It is often desirable to study the functions of viral envelope glycoproteins that are involved in attachment, membrane fusion and entry in the context of a viral particle. For example, infectivity experiments using virus particles can confirm observations made from cell-cell fusion assays, studies on virus tropism, or during the characterization of antiviral agents targeting various stages in the virus entry process [39]. However, work with infectious henipaviruses is restricted to BSL-4 containment which raises both cost and safety issues. To counter this limitation, we sought to develop a henipavirus envelope glycoprotein pseudotyping system using reporter geneencoding lentivirus vectors, which would provide a virus entry assay based on the function of the F and G glycoproteins that could be safely and routinely carried out under BSL-2 conditions.

To test this possibility, pseudotyped retrovirus particles were produced by transfection using pNL4-3-Luc-E- $\mathrm{R}^{+}$, a plasmid containing the HIV-1 proviral clone NL4-3 which encodes luciferase and does not produce the HIV-1 envelope glycoprotein [40] along with pCAGGs expression vectors encoding the $\mathrm{NiV}$ or $\mathrm{HeV} \mathrm{F}$ and $\mathrm{G}$ glycoproteins. The preparations of henipavirus glycoprotein pseudotyped virus particles and control virus particles lacking the glycoproteins were normalized for p24 content by ELISA (see Methods) and used to infect several human cell lines, 293T, U87, HOSX4T4 and TK', long known to be permissive for henipavirus-mediated cell-cell fusion $[30,41]$ and the henipavirus receptor (ephrinB2 and B3) negative and fusion and infection resistant cell line HeLa-USU [20]. Pseudotyped virus particles generated with the NiV F and $G$ glycoproteins were able to infect and produce luciferase reporter gene activity at various levels on all permissive receptor expressing cells (Figure 1A) while no signal was observed with the receptor negative HeLa-USU or with control virus particles generated by transfection with empty vector (pCAGGs). Surprisingly however, virus particles produced using the pCAGGs expression plasmids encoding the $\mathrm{HeV} F$ and G glycoproteins were consistently non-functional as measured by luciferase activity (data not shown). The expression vector pCAGGs is a mammalian expression vector with the cytomegalovirus (CMV) immediate early enhancer linked with the chicken $\beta$-actin

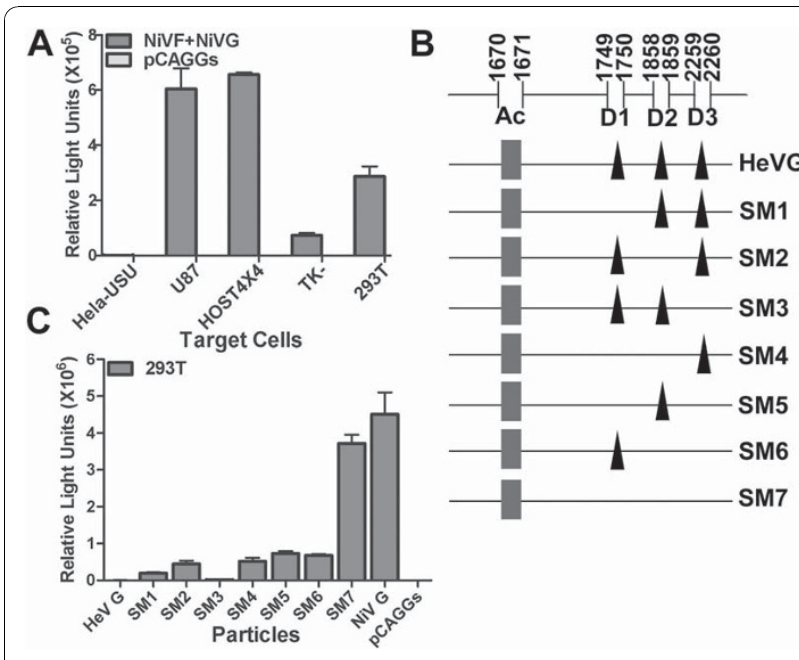

Figure 1 Henipavirus $\mathrm{F}$ and $\mathrm{G}$ bearing pseudotyped lentivirus particles. (A) Infection assay with NiV F and G glycoprotein bearing virus particles. Virus particles were prepared in 293T cells by cotransfecting the pNL4-3-Luc-E-R ${ }^{+}$HIV-1 backbone along with the NiV F and $G$ encoding vectors, or with empty vector (pCAGGs). Culture supernatants were collected $36 \mathrm{hr}$ post-transfection and filtered through a $0.45 \mu \mathrm{m}$ filter and the pseudovirus preparations were normalized by p24 ELISA. The pseudovirus preparations were used to infect receptor positive and negative cells in triplicate wells and at $48 \mathrm{hr}$ post infection, cells were lysed and assayed for luciferase reporter gene activity as described in the Methods. (B) Diagram of the panel of splice site mutants of the HeV G gene cloned into the PCAGGs vector. Putative splice donor sites are presented as black triangles and the splice acceptor site as grey squares. (C) Infection assay using pseudotyped virus particles prepared with $\mathrm{HeV} F$ along with (left to right) HeV G (wild-type) or each of the seven HeV G splice site mutants (SM1 - SM7); NiV G (wild-type); or empty vector (pCAGGs). Error bars indicate the standard error of the mean from triplicate wells.

promoter (CAG promoter) [42]. It has an intron with the splice acceptor site from the rabbit $\beta$-globin gene, which results in the splicing of the pre-mRNA, increasing the stability of the expressed mRNA and enhancing the production of an encoded protein. Although these features make pCAGGs an efficient vector for the expression of genes in the nucleus, we found it problematic for the expression of the $\mathrm{HeV}$ G glycoprotein, an RNA virus gene normally expressed in the cytoplasm of an infected cell, and expression levels of $\mathrm{HeV} \mathrm{G}$ were significantly lower in comparison to NiV G in the same system (data not shown). Analysis of the HeV G gene cloned in pCAGGs using splice site prediction software from EMBL-EBI http://www.ebi.ac.uk/asd-srv/wb.cgi?method=7 revealed 3 possible splice sites within $\mathrm{HeV} \mathrm{G}$ coding region (Figure 1B), while none were present in the NiV G glycoprotein pCAGGs construct (Additional file 1: Fig. S1). Mutations were introduced by site-directed mutagenesis to remove the predicted splice sites singly or in different combinations, keeping the amino acid coding sequence unaltered, 
and a panel of seven (SM1 - SM7) HeV G mutant clones were generated (Figure 1B).

The HeV G splice mutant constructs were then tested for expression by plasmid transfection which indicated that the removal of these predicted splice sites improved $\mathrm{HeV}$ G glycoprotein production, and removal of all three sites was optimal, and mRNA expression and alternative splicing patterns were confirmed by Northern blot analysis (results not shown). A series of pseudotyped virus particles were prepared using $\mathrm{HeV} F$ along with each of $\mathrm{HeV} \mathrm{G}$ splice mutants (SM1 - SM7). In addition, control virus particles were also prepared using $\mathrm{HeV} F$ along with empty vector (pCAGGs), wild-type $\mathrm{HeV} \mathrm{G}$, or wild-type NiV G. This series of pseudotyped virus particles were then used to infect 293T target cells, and as shown in Figure 1C, the HeV G splice mutant SM7 (3 putative splice sites removed) in combination with $\mathrm{HeV} F$ was able to produce functional pseudotyped particles, as measured by luciferase reporter gene activity, to signal levels comparable to NiV F and G bearing particles (Figure 1A). The remainder of the $\mathrm{HeV}$ G splice mutants (SM1 - SM6) did show low levels of reporter gene signal, whereas the wildtype $\mathrm{HeV} \mathrm{G}$ did not. These results demonstrate that the splice site removal by mutation in $\mathrm{HeV}$ G-SM7 restores the ability of $\mathrm{HeV} \mathrm{G}$ to be expressed in the context of pCAGGs, thus allowing its incorporation into the lentivirus particles. In addition, functional particles were also generated using $\mathrm{HeV} F$ in heterotypic combination with $\mathrm{NiV} \mathrm{G}$, confirming the previous heterotypic cell-cell fusion activities observed with the henipaviruses [30]. The heterotypic pseudotyped particles yielded reporter gene activity essentially equivalent to the $\mathrm{HeV}$ G-SM7 and $\mathrm{HeV} F$ particles (Figure 1C) and similar to the signals obtained with NiV F and G bearing particles (Figure 1A).

To confirm these findings and demonstrate an expanded utility of the henipavirus envelope glycoprotein pseudotyping systems, NiV and $\mathrm{HeV} \mathrm{F}$ and G glycoprotein bearing lentivirus particles were prepared with the GFP reporter gene encoding construct pNL4-3-GFP-E- $\mathrm{R}^{+}$and used to infect receptor positive $293 \mathrm{~T}$ cells (Figure 2). Here, productively infected cells were visualized using a fluorescent microscope $48 \mathrm{hrs}$ post-infection and fluorescent cells were observed only in those cells infected with pseudotyped virions prepared with either NiV F and NiV G or $\mathrm{HeV} F$ and $\mathrm{HeV}_{\mathrm{SM}}$. No GFP expressing cells were observed in those wells infected with virions prepared with empty vector (pCAGGs) or virus particles prepared with $\mathrm{HeV} F$ and wild-type $\mathrm{HeV}$ G.

\section{Specificity of henipavirus envelope glycoprotein pseudotyped lentivirus particles}

To examine the cellular infection specificity of the $\mathrm{HeV}$ and NiV F and G pseudotyped particles, several henipavirus specific reagents capable of blocking virus infection

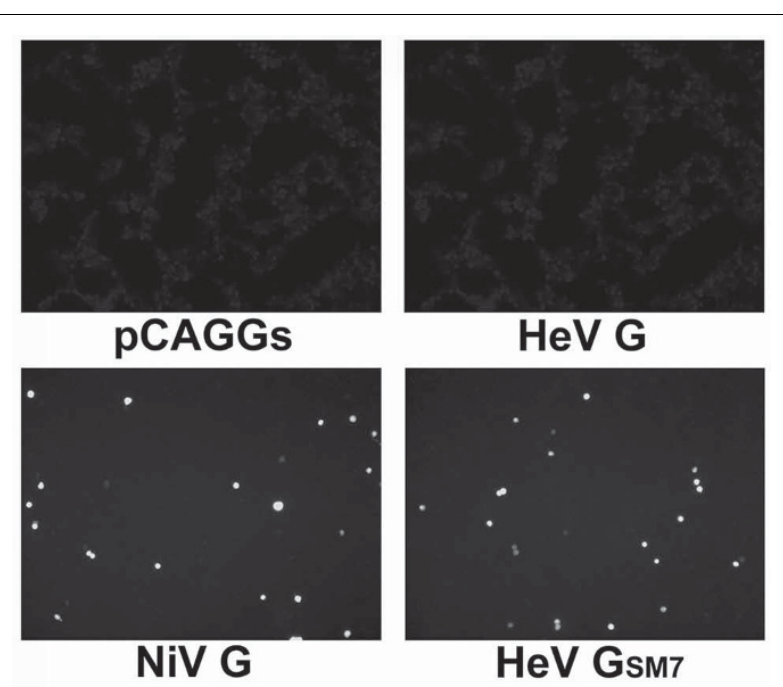

Figure 2 Henipavirus $F$ and $G$ bearing pseudovirus infection assay with GFP-encoding lentivrus particles. 293T cells were cotransfected with the pNL4-3-GFP-E-R ${ }^{+}$HIV-1 backbone plasmid along with either empty PCAGGs vector, homologous combinations of NiV F/G, HeV F/G, or HeV F with HeV GSM7. The supernatants were collected $36 \mathrm{hr}$ post-transfection and processed as detailed in the methods. Receptor positive 293T cells were infected with pseudovirions and scored for transduction efficiency by counting the number of GFP positive green cells $48 \mathrm{hr}$ post-infection using Olympus IX81 fluorescent microscope.

were tested for their ability to inhibit the infection of the henipavirus pseudotypes. Virus particles were prepared as before and then mixed with various inhibitors (Figure 3). The henipavirus specific peptide fusion inhibitor NiV-FC2, a 36 amino acid peptide corresponding to the henipavirus heptad repeat region 2 (HR-2) of the F glycoprotein $[39,41]$, completely blocked the entry of the henipavirus pseudotypes as measured by luciferase reporter gene activity. The NiV-FC2 peptide functions in an analogous manner to the HIV-1 specific fusion inhibitor enfuvirtide (Fuzeon ${ }^{\text {tw }}$, formerly T-20) [43,44], and specifically blocks the formation of the class 1 fusion glycoprotein structure known as the 6-helix bundle of the F glycoprotein preventing F-mediated membrane fusion and subsequent virion entry. A scrambled version of the peptide (Sc NiV-FC2) was used as a negative control. Infection specificity was also examined by inhibition with the cross-reactive anti-henipavirus G glycoprotein human monoclonal antibody (mAb) m102.4 $[45,46]$. The m102.4 mAb neutralizes henipaviruses by specifically binding and blocking the ephrin-B2 and -B3 receptor-binding region on the henipavirus $\mathrm{G}$ glycoprotein. As shown in Figure 3, infection of either the $\mathrm{HeV}$ or $\mathrm{NiV}$ pseudotypes was completely blocked by $\mathrm{mAb}$ m102.4 confirming that their entry and resultant luciferase signal is specifically mediated by the attachment and subsequent fusion triggering functions of their 


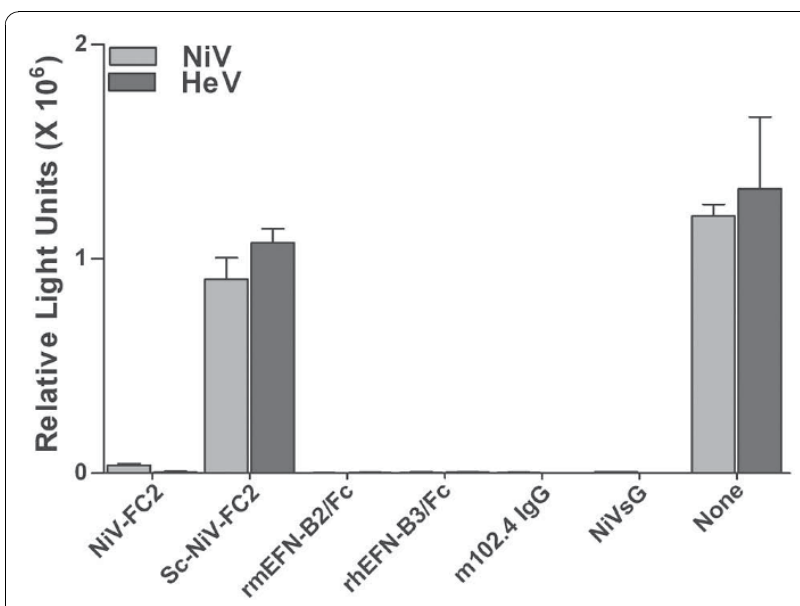

Figure 3 Infection specificity of henipavirus F and G bearing pseudovirions. The HeV and NiV envelope glycoprotein pseudotyped virus particles were preincubated with $2 \mu \mathrm{g}$ of NiVFC2, Sc-NiV-FC2, soluble, murine ephrin-B2, or soluble human ephrin-B2, mAb m102.4 lgG, recombinant NiV sG, or nothing (control), for $1 \mathrm{hr}$ at $4^{\circ} \mathrm{C}$ and then receptor positive 293T cells were infected (transduced) with the various treated pseudotyped virus preparations in triplicate wells. After $1 \mathrm{hr}$ incubation, complete media was added and infections were continued for an additional 48 hrs. Cells were then lysed and assayed for luciferase reporter gene activity as described in the Methods. Error bars indicate the standard error of the mean from triplicate wells.

henipavirus $\mathrm{G}$ glycoproteins. In addition, the binding and infection of the henipavirus pseudotypes to target cells could be blocked by recombinant, soluble ephrin$\mathrm{B} 2$ and $-\mathrm{B} 3$ receptors (Figure 3 ). $\mathrm{HeV}$ and NiV F and G bearing particles pre-incubated with soluble ephrin-B2 or -B3 were unable to infect host cells as was previously shown with infectious virus [20]. Also, in a reciprocal manner, recombinant soluble NiV G (sG) could block entry of either henipavirus pseudotype as was similar to earlier observations made with $\mathrm{HeV}$ sG in infectious virus entry. Together, these results demonstrate the specificity of the henipavirus $\mathrm{F}$ and $\mathrm{G}$ glycoprotein bearing pseudotyped virus entry assay and its potential utility in screening specific henipavirus entry inhibitors.

\section{Influence of the henipavirus F glycoprotein cytoplasmic tail on processing and function}

Previous studies have demonstrated that efficient incorporation of heterologous envelope glycoproteins into HIV-1 or murine leukemia virus (MLV) particles often depended on the removal of part or all of the cytoplasmic tail domains from the pseudotyping glycoproteins [38,47-49]. To explore whether a similar feature was occurring in the henipavirus pseudotyping system here, a series of seven cytoplasmic tail truncation mutations in each henipavirus $\mathrm{F}$ glycoprotein were generated, designated $\mathrm{F} \Delta \mathrm{Ct} 1$ to $\mathrm{F} \Delta \mathrm{Ct} 7$, by introducing translational stop codons into the coding sequence of the $\mathrm{NiV}$ and $\mathrm{HeV} F$ gene (Figure 4). The F $\Delta \mathrm{Ct} 1$ and $\mathrm{F} \Delta \mathrm{Ct} 2$ constructs of both the $\mathrm{NiV}$ and $\mathrm{HeV} \mathrm{F}$, differ by only one additional deleted valine residue to better ensure complete removal of the cytoplasmic tail domain.

Because cytoplasmic tail truncations of membrane anchored proteins could affect proper folding and transport, we first examined the levels of cell surface expressed $\mathrm{F}$ and compared the series of truncated mutant $\mathrm{F}$ constructs to each wild-type $\mathrm{F}$, using a cell surface biotinylation assay [50]. The series of $\mathrm{NiV}$ and $\mathrm{HeV} \mathrm{F}$ glycoprotein mutants and each wild-type $\mathrm{F}$ were expressed by plasmid transfection in HeLa-USU cells, both in the presence and absence of their homologous $\mathrm{G}$ glycoprotein partner, and surface proteins were biotin labeled, precipitated with Avidin-agarose, and analyzed by Western blot assay using an $F_{1}$ specific antisera

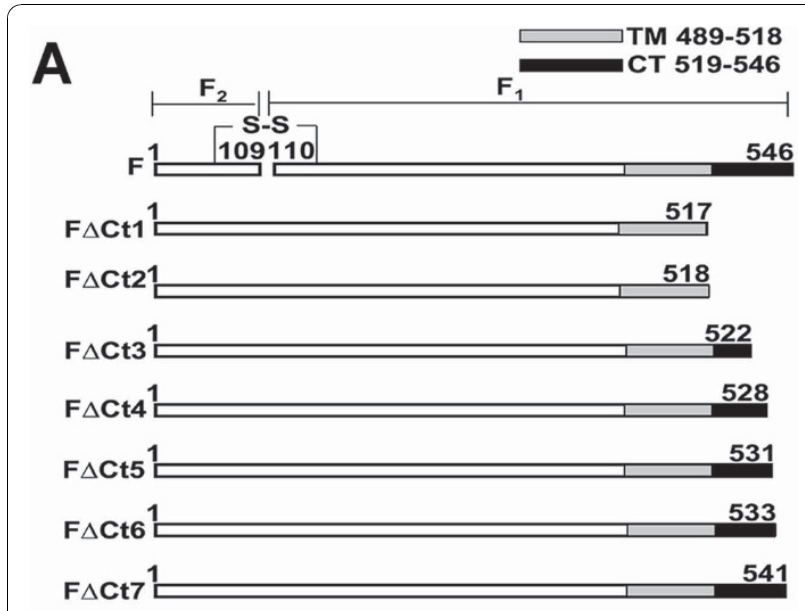

B

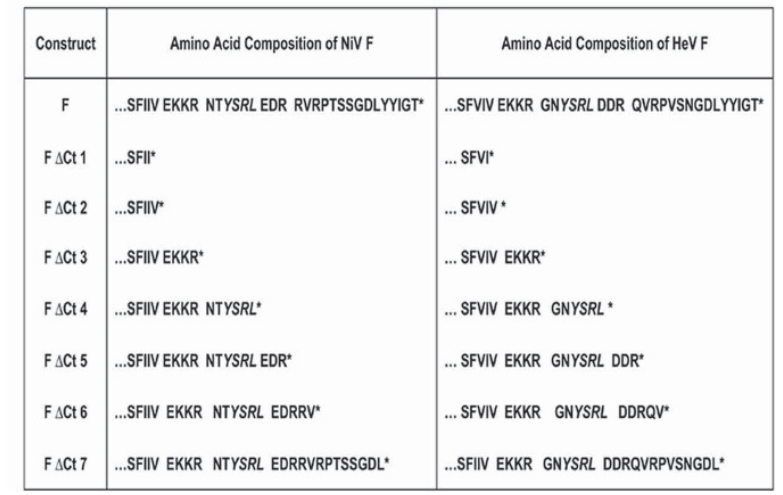

Figure 4 Schematic diagram of truncation mutants in the fusion glycoprotein. (A) A schematic representation of the $F$ glycoprotein truncation mutants. The transmembrane and the cytoplasmic tail regions are marked along with the disulfide bond linking $F_{1}$ and $F_{2}$. The nomenclature for the constructs is shown on the left and the position of stop codon on the right. (B) The amino acid composition of truncation mutants near the truncation site within the F glycoprotein of both HeV and NiV. 
(Figure 5). The wild-type $\mathrm{NiV} \mathrm{F}_{0}$ precursor was cleaved and detected. $\mathrm{F} \Delta \mathrm{Ct} 1, \mathrm{~F} \Delta \mathrm{Ct} 2$ appeared less efficiently cleaved (levels of $F_{1}$ versus $F_{0}$ ) as compared to wild-type $\mathrm{NiV}$ F. A significant amount of each of the NiV F $\Delta \mathrm{Ct} 3$, $\mathrm{F} \Delta \mathrm{Ct} 4, \mathrm{~F} \Delta \mathrm{Ct} 5, \mathrm{~F} \Delta \mathrm{Ct} 6$ and $\mathrm{F} \Delta \mathrm{Ct} 7$ constructs were cleaved, with the F $\Delta \mathrm{Ct} 6$ appearing highly processed although its overall expression was lower in comparison to others. The ratio of cleaved to uncleaved $F\left(F_{1}\right.$ to $\left.F_{0}\right)$ on the cell surface was approximately equal (1:1) when the complete retention and endocytosis motif (YSRL) $[51,52]$ was retained, beginning with the $\mathrm{F} \Delta \mathrm{Ct} 4$ constructs. Notably, the coexpression of NiV G did not appear to significantly alter the expression and cleavage patterns of NiV F (Figure 5).

The retention of amino acid residues from the endocytosis motif YSRL to residues EDRRV in the cytoplasmic tail appeared to allow for more efficient $F_{0}$ processing, as evidenced by the greater levels of $F_{1}$ observed with these $\mathrm{NiV}$ constructs (NiV F $\Delta \mathrm{Ct} 4$ to $\mathrm{F} \Delta \mathrm{Ct} 7$ ) (Figure 4) in comparison to NiV F $\Delta \mathrm{Ct} 1, \mathrm{~F} \Delta \mathrm{Ct} 2$ and $\mathrm{F} \Delta \mathrm{Ct} 3$ which lack the YSRL motif. In addition, the cell surface levels of $F$ (primarily $F_{0}$ ) observed with the $\mathrm{F} \Delta \mathrm{Ct} 1, \mathrm{~F} \Delta \mathrm{Ct} 2$ and $\mathrm{F} \Delta \mathrm{Ct} 3$ constructs appeared greater in comparison to the $\mathrm{F} \Delta \mathrm{Ct} 4, \mathrm{~F} \Delta \mathrm{Ct} 5, \mathrm{~F} \Delta \mathrm{Ct} 6$ and $\mathrm{F} \Delta \mathrm{Ct} 7$ constructs, and this mostly likely reflects the reduced

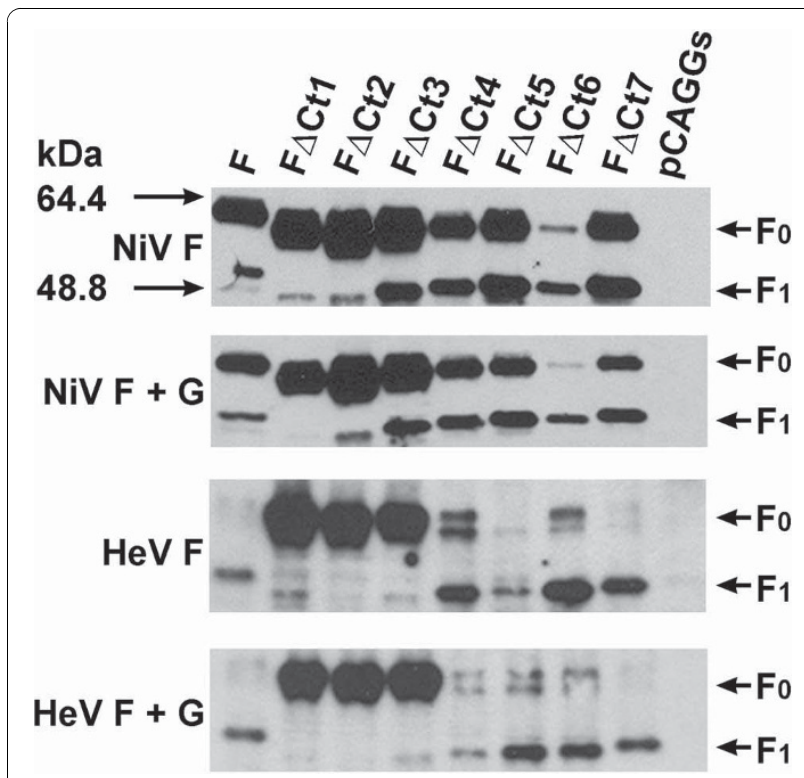

Figure 5 Cell surface expression of truncation mutants of the henipavirus $\mathbf{F}$ glycoprotein. The various F cytoplasmic tail truncation mutants alone or together with their $G$ glycoprotein partner were transfected into HeLa-USU cells. At 24 hr post transfection, cell surface proteins were biotinylated and precipitated with Avidin agarose beads, and the precipitated proteins were processed for Western blot analysis as detailed in the Methods and probed using the anti $F_{1}$ specific antisera. This experiment was performed twice and representative experiment is shown in the figure. ability of the $F_{0}$ precursor to be endocytosed and processed by Cathepsin L $[27,53]$. Similar results were obtained when the series of $\mathrm{HeV} \mathrm{F}$ cytoplasmic tail truncation mutants were examined in parallel, and the $\mathrm{HeV} F$ constructs $\mathrm{F} \Delta \mathrm{Ct} 1, \mathrm{~F} \Delta \mathrm{Ct} 2$ and $\mathrm{F} \Delta \mathrm{Ct} 3$ revealed greater cell surface expression levels of $F_{0}$ with less efficient processing as measured by the detection of $\mathrm{F}_{1}$, whereas the $\mathrm{HeV} F$ constructs, $\mathrm{F} \Delta \mathrm{Ct} 4$ through $\mathrm{F} \Delta \mathrm{Ct} 7$ revealed greater $\mathrm{F}_{0}$ precursor processing but perhaps an overall lower level of expression (Figure 5). A variable and doublet appearance of $\mathrm{HeV} \mathrm{F}_{0}$ has been observed previously $[30,54,55]$. As with the NiV F truncation mutants the coexpression of the $\mathrm{HeV} \mathrm{F}$ panel along with their $\mathrm{HeV} \mathrm{G}$ glycoprotein partner did not significantly alter the $\mathrm{HeV} F$ expression and cleavage patterns observed in cell surface biotinylation assays.

Having characterized the expression and processing of the cytoplasmic tail truncation mutants of both $\mathrm{NiV}$ and $\mathrm{HeV} F$ glycoprotein, we next examined their biological function in cell-cell membrane fusion assays. Membrane fusion was assessed using the well-characterized vaccinia virus-based, reporter-gene, cell-cell fusion assay [56]. This assay has also been used extensively in earlier reports on the characterization of $\mathrm{HeV}$ and $\mathrm{NiV}$ mediated membrane fusion and tropism [30,41,57]. The series of $\mathrm{F}$ glycoprotein truncation mutants for both $\mathrm{HeV}$ and $\mathrm{NiV}$ were expressed, along with their respective partner G glycoprotein, in HeLa-USU cells (effector cells) and cell-cell fusion reactions were carried out using target cells of either receptor negative HeLa-USU (control) or fusion permissive 293T cells, and results are shown in Figure 6. For NiV F, the removal of most of the cytoplasmic tail domain from $\mathrm{F}$ (F $\Delta \mathrm{Ct} 1$ and $\mathrm{F} \Delta \mathrm{Ct} 2$ ), which also reduced $\mathrm{F}_{0}$ processing, impaired their fusogenic potential as would be expected, whereas the fusogenic activity of NiV F $\Delta \mathrm{Ct} 3, \mathrm{~F} \Delta \mathrm{Ct} 4, \mathrm{~F} \Delta \mathrm{Ct} 5, \mathrm{~F} \Delta \mathrm{Ct} 6$ and $\mathrm{F} \Delta \mathrm{Ct} 7$ were either equivalent or slightly elevated in comparison to wild-type NiV F. The cell-cell fusion assay with the series of $\mathrm{HeV} F$ truncation mutants generated slightly more variable results in contrast to $\mathrm{NiV}$ $\mathrm{F}$, though all possessed some fusogenic activity. In general there was only a slight reduction in fusion with $\mathrm{HeV} F, \mathrm{~F} \Delta \mathrm{Ct} 1$ and $\mathrm{F} \Delta \mathrm{Ct} 2$, while $\mathrm{F} \Delta \mathrm{Ct} 3, \mathrm{~F} \Delta \mathrm{Ct} 5$ and $\mathrm{F} \Delta \mathrm{Ct} 6$ were essentially equivalent to wild-type $\mathrm{HeV} \mathrm{F}$, while lower fusion signals were seen with $\mathrm{HeV} \mathrm{F} \Delta \mathrm{Ct} 4$ and $\mathrm{F} \Delta \mathrm{Ct} 7$, which could be related to an overall lower expression level as seen in Figure 5. A comparison of the results in Figure 5 and Figure 6 suggests that NiV F processing appears to correlate with cell-cell fusion signals; whereas cell-cell fusion activity was readily apparent in several $\mathrm{HeV} \mathrm{F}$ truncation mutants possessing a markedly lower level of $\mathrm{F}_{0}$ processing, however these are independent experiments and a direct comparison may be miss-leading. 


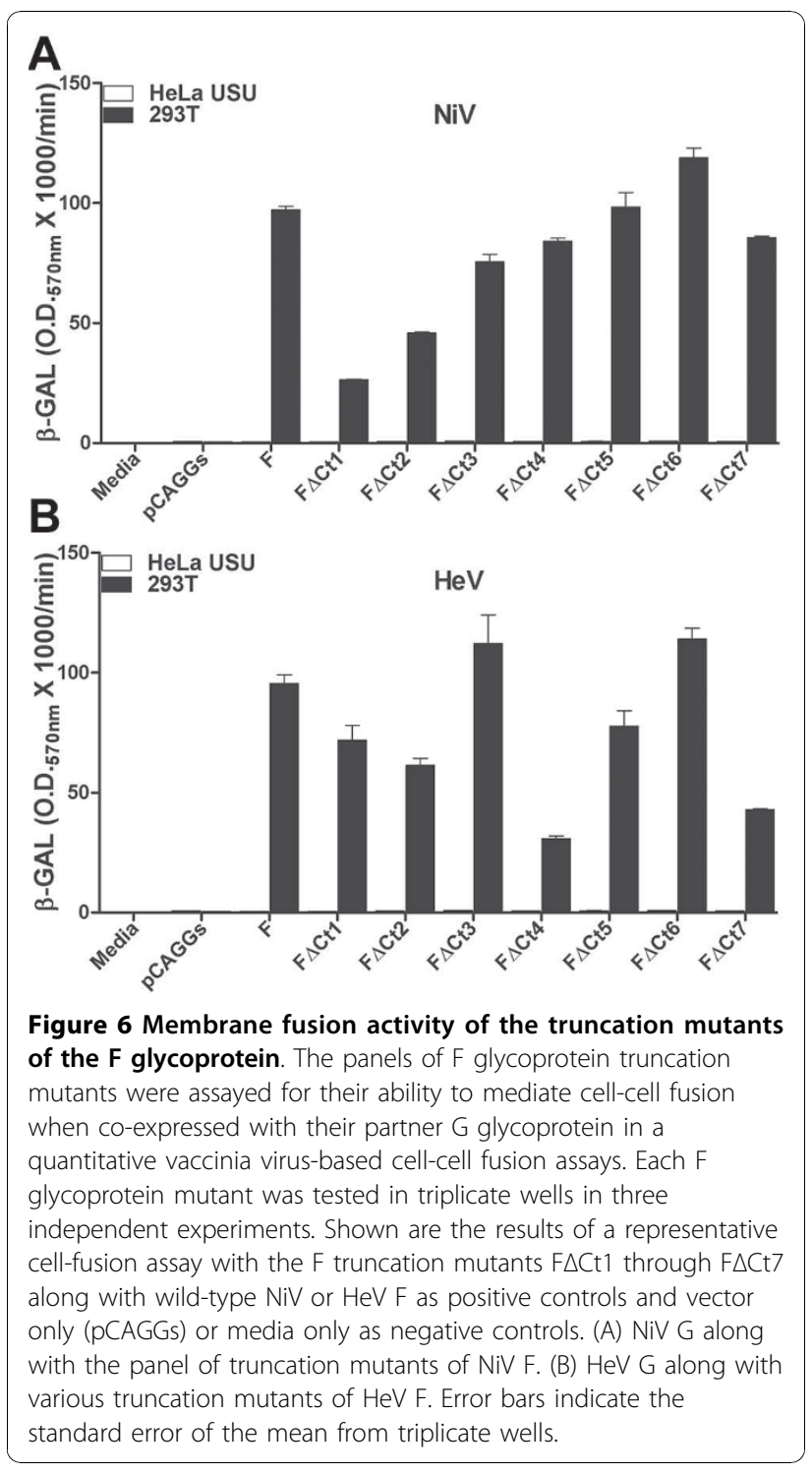

\section{Incorporation and function of truncated F glycoproteins into lentivirus particles}

We next examined the efficiency of the various cytoplasmic tail truncation mutants of the $\mathrm{NiV}$ and $\mathrm{HeV}$ F glycoproteins to be incorporated into lentivirus-based pseudotypes. Pseudotyped lentivirus particles were prepared as before using the series of cytoplasmic tail truncation mutants along with their partner G glycoprotein. Three types of control virus particles were also prepared using either empty vector (pCAGGs) or each species of wild-type F glycoprotein alone or each species of G glycoprotein alone. Pseudotyped virus particle preparations were filtered, purified by centrifugation through a sucrose cushion, normalized for p24 content by ELISA and used to infect 293T target cells. Following infection and incubation for $48 \mathrm{~h}$, cells were processed and luciferase activity was measured. As shown in Figure 7A and $7 \mathrm{~B}$, pseudovirus particles prepared using the truncation mutants $\mathrm{F} \Delta \mathrm{Ct} 1, \mathrm{~F} \Delta \mathrm{Ct} 2$, and $\mathrm{F} \Delta \mathrm{Ct} 3 \mathrm{~F}$ glycoproteins produced significantly greater levels of luciferase activity as compared to virus particles made with wild-type F. To evaluate whether the differences in infectivity, as measured by luciferase reporter gene activity, by the various pseudovirus types correlated to the extent of incorporation of the mutant $\mathrm{F}$ glycoproteins into lentivirus particles, equal amounts of virus particles based on p24 content were lysed and analyzed by Western blot. This analysis revealed that incorporation of $\mathrm{F}$ into either the $\mathrm{NiV}$ or $\mathrm{HeV}$ pseudotyped virions was greater with the $\mathrm{F} \Delta \mathrm{Ct} 1, \mathrm{~F} \Delta \mathrm{Ct} 2$ and $\mathrm{F} \Delta \mathrm{Ct} 3$ constructs, and that $\mathrm{F}_{0}$ was the predominant species present in the virions (Figure $7 \mathrm{C}$ ). These results together with cell surface expression pattern of the $\mathrm{NiV}$ and $\mathrm{HeV}$ wild-type and truncation mutants demonstrate that, in general, the amount of incorporation of the F glycoproteins in the pseudotyped particles appears to correlate well with the level of expression of these proteins on the surface of the producer cells. This was also true in the amount of wild-type $\mathrm{NiV}$ or $\mathrm{HeV} F$ alone bearing particles which can be noted when comparing Figure 5 and Figure 7C. Removal of the endocytosis motif from the fusion protein prevents its transportation to the endosome and subsequent cleavage of $F_{0}$ into $F_{1}$ and $F_{2}$ by Cathepsin $\mathrm{L}$, which explains the predominance of $\mathrm{F}_{0}$ in the $\mathrm{F} \Delta \mathrm{Ct} 1, \mathrm{~F} \Delta \mathrm{Ct} 2$ and $\mathrm{F} \Delta \mathrm{Ct} 3$ constructs which lack the endocytosis motif YSRL. Interestingly, in both the NiV and $\mathrm{HeV} F$ glycoprotein mutant series, the higher infectivity of the $\mathrm{F} \Delta \mathrm{Ct} 1, \mathrm{~F} \Delta \mathrm{Ct} 2$ and $\mathrm{F} \Delta \mathrm{Ct} 3$ bearing pseudotypes in comparison to wild-type was notable, and might be attributed to the greater levels of incorporation of these $\mathrm{F}$ glycoproteins into the particles, except in the case of wild-type NiV F and G bearing particles and the reason for this later observation is unclear at present. Alternatively however, and also of interest is that the high infectivity signal and predominance of $\mathrm{F}_{0}$ in the pseudotypes prepared with $\mathrm{F} \Delta \mathrm{Ct} 1, \mathrm{~F} \Delta \mathrm{Ct} 2$ and $\mathrm{F} \Delta \mathrm{Ct} 3$ could argue for a role of endocytosis followed by Cathepsin $\mathrm{L}$ processing of $\mathrm{F}_{0}$ and subsequent productive fusion and infection.

\section{Discussion}

In the present study we have detailed a new and readily adaptable, reporter-gene containing, lentivirus-based pseudotyping system which utilizes functional $F$ and $G$ envelope glycoproteins of the henipaviruses; $\mathrm{NiV}$ and $\mathrm{HeV}$. Importantly, like other virus envelope glycoprotein pseudotyping systems, this assay can be conducted safely under BSL-2, a condition which is relevant considering the otherwise highly pathogenic nature of infectious $\mathrm{NiV}$ and $\mathrm{HeV}$. We also demonstrate, by several measures, that 


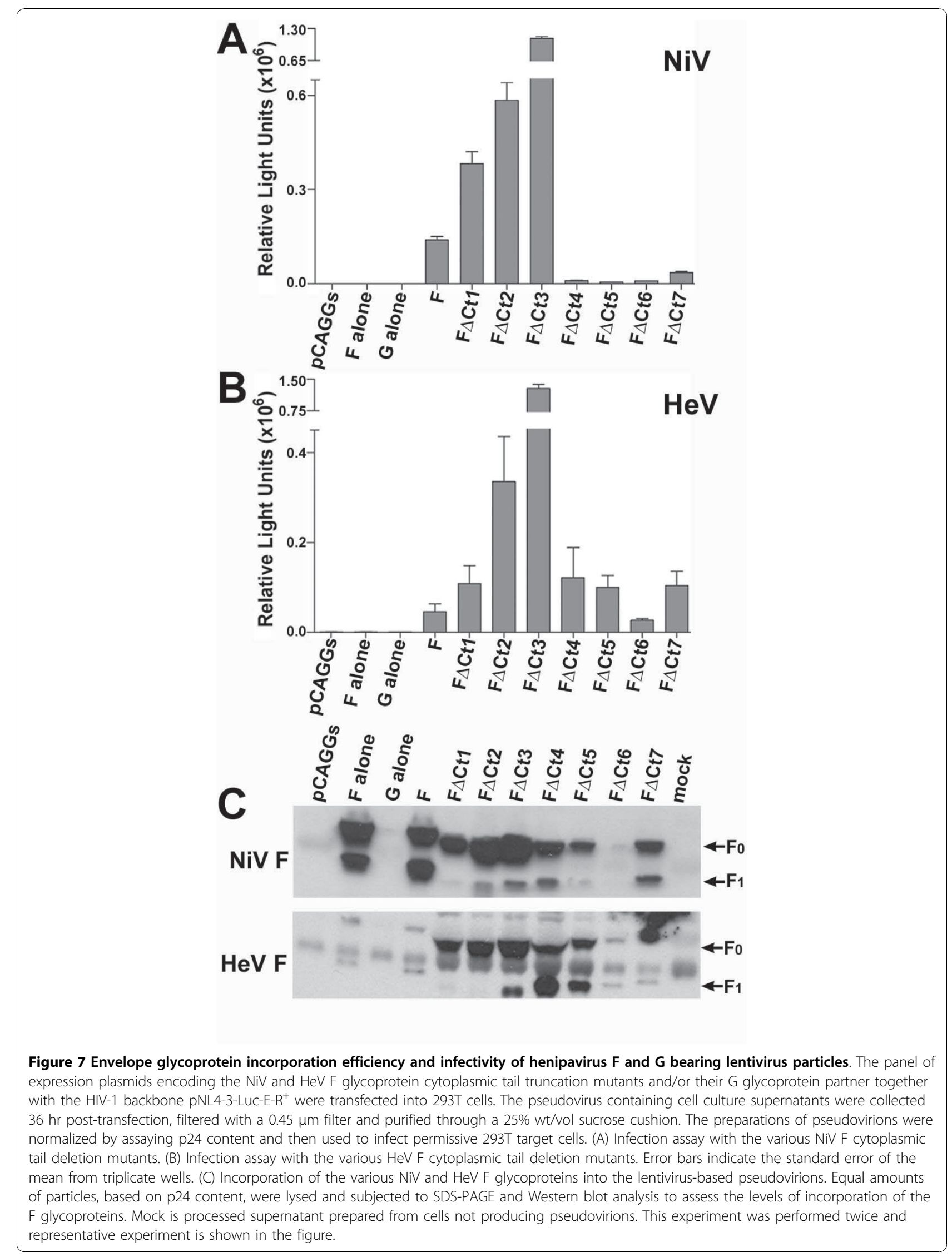


this henipavirus pseudotyping system faithfully recapitulated the natural $\mathrm{NiV}$ or $\mathrm{HeV}$ cell attachment and viral glycoprotein-mediated membrane fusion stages of infection.

The henipaviruses bind and infect their host cells by a specific attachment step to the cell surface expressed proteins ephrin-B2 and -B3 [20-23]. The current and widely accepted model of paramyxovirus mediated membrane fusion postulates that upon receptor binding the viral attachment glycoprotein triggers conformational changes in the $\mathrm{F}$ glycoprotein, a class I viral fusion glycoprotein. The receptor-induced triggering event is presumed to involve direct contacts between an attachment and fusion glycoprotein and this activation process facilitates a series of conformational changes in $\mathrm{F}$ and the glycoprotein transitions into its post-fusion, six-helix-bundle conformation concomitant with the merging of the viral membrane envelope and the host cell plasma membrane $[26,58]$. However, all of the details of the entire receptor binding and fusion activation process have yet to be defined. An important feature of many class I fusion glycoproteins is the two $\alpha$-helical regions referred to as heptad repeat (HR) domains that are involved in the formation of the sixhelix-bundle structure $[59,60]$. HR-1 is located proximal to the amino $(\mathrm{N})$-terminal fusion peptide and HR-2 precedes the transmembrane domain near the carboxyl $(\mathrm{C})$ terminus. Peptide sequences from either HR domain of the $\mathrm{F}$ glycoprotein of several paramyxoviruses, including $\mathrm{HeV}$ and $\mathrm{NiV}$, have been shown to be inhibitors of the F-mediated membrane fusion step in both cell-cell fusion and virus infection assays [30,39,41,57,61-66]. Here, as has been shown with infectious virus or cellcell fusion assays, the infection by $\mathrm{NiV}$ and $\mathrm{HeV} F$ and $G$ lentivirus pseudotypes was completely blocked by the HR-2 based fusion inhibiting peptide (NiV-FC2) [39].

A number of other tests were also conducted to demonstrate the specificity of the henipavirus pseudotyping system in addition to using the henipavirus peptide fusion inhibitors. In competition assays, the infection of the pseudotypes could also be specifically blocked using recombinant, soluble ephrin-B2 or ephrin-B3 receptor proteins as was previously shown with both henipavirus-mediated membrane fusion as well as live virus infection assays[20]. In a similar fashion, recombinant, soluble henipavirus $G$ glycoprotein (sG) was also able to completely inhibit the infection of either $\mathrm{HeV}$ or $\mathrm{NiV}$ pseudotypes by blocking receptor binding, which had been demonstrated previously in both henipavirus-mediated membrane fusion and live virus infection assays [28]. Finally, the infection by the $\mathrm{NiV}$ and $\mathrm{HeV}$ pseudotypes could also be completely blocked using a well-characterized, cross-reactive human $\mathrm{mAb}(\mathrm{m} 120.4)$ that is specific for the henipavirus $\mathrm{G}$ glycoprotein $[15,46]$. Thus, by a wide variety of wellknown and well-characterized approaches the functional henipavirus envelope glycoprotein pseudotyped lentivirus assay system developed here, accurately recapitulates the receptor binding, membrane fusion and infection stages of live $\mathrm{HeV}$ and $\mathrm{NiV}$.

Because of both the highly pathogenic features of $\mathrm{NiV}$ and $\mathrm{HeV}$, which restricts the use of infectious virus to BSL-4 containment, and the labor intensive nature and challenges associated with a reverse genetics approach, extensive and detailed structural and functional studies on the henipavirus envelope glycoproteins in the context of a viral particle has been limited. To demonstrate the utility of the henipavirus pseudotyping system here, we generated and tested an extensive panel of cytoplasmic tail domain truncation mutants of the $\mathrm{NiV}$ and $\mathrm{HeV} F$ glycoprotein, and examined the influence of this domain of $\mathrm{F}$ on its ability to be incorporated into this budding particles as well as its fusion activity in the context of a viral particle.

Here, it was observed that the deletion of essentially the entire F cytoplasmic tail domain, most notably with the NiV F glycoprotein and to a lesser degree with that of $\mathrm{HeV} \mathrm{F}$, impaired their fusogenic activity in the context of a cell-cell fusion assay. These findings were in contrast with previous observations made on the envelope glycoproteins of certain lentiviruses. Studies with human immunodeficiency virus type 2 (HIV-2) and simian immunodeficiency virus (SIV) envelope (Env) glycoproteins have shown that cytoplasmic domain truncation mutants exhibit significantly enhanced Env fusogenic activity as measured by syncytium formation $[67,68]$. In addition, studies with murine leukemia virus have demonstrated that naturally occurring late cleavage of a small carboxy terminal sequence, designated as the $\mathrm{R}$ peptide or $\mathrm{p} 2 \mathrm{E}$, in the cytoplasmic tail results in considerably enhanced cell-to-cell fusion activity $[69,70]$. Whereas for a paramyxovirus $\mathrm{F}$ glycoprotein, cytoplasmic tail deletions in simian virus 5 (SV5) [71], Newcastle disease virus [72], and human parainfluenza virus (HPIV) type 3 (HPIV-3) revealed significantly reduced syncytium formation, except in one example with HPIV2 , where similar deletions did not affect membrane fusion [73]. Overall, with the exception of the results with HPIV-2, these studies also demonstrated that subsequent additions of parts of the deleted cytoplasmic tail sequences restored the fusogenic potential of those $\mathrm{F}$ glycoproteins. In the case of henipaviruses, one explanation to account for the reduced fusion activity of the entire cytoplasmic tail deleted constructs is poor endocytosis and subsequent Cathepsin $\mathrm{L}$ processing of $\mathrm{F}_{0}$ and the analysis of the surface expressed levels of $\mathrm{NiV}$ $\mathrm{F}_{0}$ versus $\mathrm{F}_{1}$ in the cytoplasmic tail domain truncation mutants support this conclusion, but to a lesser extent with that of the $\mathrm{HeV} \mathrm{F}$ truncation mutants. 
However, although the cell-cell fusogenic results with the truncation constructs of the henipavirus F glycoproteins reported here were similar to the majority of the observations made with other paramyxoviruses, whether as a result of $F_{0}$ precursor processing or by some other mechanism, the cytoplasmic tail deleted $\mathrm{HeV}$ and $\mathrm{NiV} \mathrm{F}$ glycoproteins in the context of the virus particle pseudotyping system, revealed an opposing result. In general, the higher levels of pseudotyped particle infectivity signal correlated with an overall greater level of incorporated $\mathrm{F}$ glycoprotein. Interestingly however, the highest luciferase signals in the virus infection assays also correlated with a greater level of unprocessed $F_{0}$ in the particles, particularly with $\mathrm{F} \Delta \mathrm{Ct} 1, \mathrm{~F} \Delta \mathrm{Ct} 2$ and $\mathrm{F} \Delta \mathrm{Ct} 3$ in which most of the cytoplasmic tail was deleted. Potentially, the greater luciferase signals in these instances ( $\mathrm{F} \Delta \mathrm{Ct} 1, \mathrm{~F} \Delta \mathrm{Ct} 2$ and $\mathrm{F} \Delta \mathrm{Ct} 3$ ) could be due to particle endocytosis following receptor binding [74] and subsequent $\mathrm{F}_{0}$ processing by Cathepsin $\mathrm{L}$ [27]. The pseudotyping system described here offers one system, albeit artificial, to explore the possibility of a productive early endocytic route of henipavirus infection. Taken together, this henipavirus pseudotyping system shown here offers a useful tool for measuring not only henipavirus entry and assaying and characterizing virus neutralizing antibodies and virus entry inhibitors, but also offers a highly versatile platform for studying $F$ and $G$ glycoprotein function in the context of a virus particle during infection, and one that can readily assay numerous variations or mutants of either or both the $F$ and $G$ henipavirus glycoproteins.

\section{Conclusions}

Functional henipavirus envelope glycoprotein pseudotyped, reporter gene encoding, lentivirus particles could be readily produced, concentrated by ultracentrifugation and stored frozen without loss of infectivity. These henipavirus pseudotyped particles maintained the same cellular tropism characteristics as authentic $\mathrm{NiV}$ and $\mathrm{HeV}$, and infection of host cells by these particles could be specifically inhibited by various antiviral agents that target the henipaviruses. This henipavirus glycoprotein pseudotyped virus infection assay can be conducted safely under BSL-2 conditions and its utility in analyzing the viral glycoprotein function, of otherwise BSL-4 restricted agents, in the context of a virus particle was demonstrated in the characterization of cytoplasmic tail truncated versions of the F glycoprotein. This new henipavirus pseudotyping system will be a useful tool for measuring $\mathrm{HeV}$ and $\mathrm{NiV}$ entry and studying their $\mathrm{F}$ and $\mathrm{G}$ glycoprotein function in the context of virus particle, as well as in assaying and characterizing neutralizing antibodies and virus entry inhibitors.

\section{Methods}

\section{Cells and culture conditions}

U87 and HuTK $143 \mathrm{~B}$ were obtained from the American Type Culture Collection (ATCC). Recombinant human osteosarcoma cells bearing CD4 and CXCR4 (HOST4X4) were obtained from the NIH AIDS Research and Reference Reagent Program [75]. The 293T cells were obtained from Dr. G. Quinnan (Uniformed Services University). HeLa-USU cell line has been described previously [20]. HeLa-USU, U87, HOST4X4 and 293T cells were maintained in Dulbecco's modified Eagle's medium (Quality Biologicals, Gaithersburg, MD) supplemented with $10 \%$ cosmic calf serum (CCS) (HyClone, Logan, UT) and $2 \mathrm{mM}$ L-glutamine (DMEM-10). All cell cultures were maintained at $37^{\circ} \mathrm{C}$ in a humidified $5 \% \mathrm{CO}_{2}$ atmosphere.

\section{Plasmids}

The $\mathrm{HeV}$ and NiV F and G envelope glycoproteins were transiently expressed using the mammalian expression vector pCAGGs which contains the CAG promoter and is composed of the cytomegalovirus immediate early enhancer and the chicken $\beta$-actin promoter [42]. The HIV-1 pNL4-3-Luc-E-R ${ }^{+}$or pNL4-3-GFP-E-R ${ }^{+}$backbone plasmids encoding the luciferase (Luc) [40] or green fluorescence protein (GFP) reporter gene were provided by Dr. R. Doms (University of Pennsylvania).

\section{Antibodies, recombinant proteins and peptides}

The henipavirus $G$ and $F$ glycoproteins were detected with a cross-reactive polyclonal mouse antiserum raised against recombinant, soluble $\mathrm{HeV} \mathrm{G}[23,50]$ or a rabbit polyclonal henipavirus $F_{1}$-specific antiserum provided by Dr. L-F. Wang (Australian Animal Health Laboratory, Geelong, Australia) respectively. The human monoclonal antibody (mAb) m102.4 IgG used for inhibition of virus entry $[15,45,46]$ was provided by Dr. D. Dimitrov (National Cancer Institute-Frederick, National Institutes of Health). The fusion inhibiting peptide NiV-FC2 corresponding to the $\mathrm{HR} 2$ region of $\mathrm{NiV} F$ and the nonfusion inhibiting scrambled control peptide Sc-NiV-FC2 have been previously described [39]. Recombinant, soluble ephrin-B2 and -B3 were from R\&D Systems, Minneapolis, MN. Recombinant, soluble NiV G (NiV sG) has been previously described [76]

\section{Fusion (F) glycoprotein constructs and mutagenesis} Full-length cDNA clones of the $\mathrm{NiV}$ and $\mathrm{HeV} F$ glycoprotein genes $[30,41]$ each including the Kozak consensus sequence (CCACC) appended upstream of the initial ATG [77] were subcloned into pCAGGs, generating the NiV F-pCAGGs and HeV F-pCAGGs expression vectors. The cytoplasmic tail domain truncation mutants of 
$\mathrm{NiV}$ and $\mathrm{HeV} \mathrm{F}$ were generated by introducing stop codons corresponding to amino acid positions 517,518 , $522,528,531,533$ and 541 of the full-length F glycoprotein by standard PCR techniques. The NiV F-pCAGGs and $\mathrm{HeV}$ F-pCAGGs plasmids were used as templates, and the 5' primer included an external EcoRI site, the Kozak consensus sequence (CCACC) and F-specific sequence. The various 3' primers included $\mathrm{F}$ specific sequence, a stop codon at the desired location and an external KpnI site. All PCR products were gel purified and cloned into the TOPO vector (Invitrogen) and subsequently subcloned into pCAGGs, generating constructs NiV F $\Delta$ Ct1 through $\mathrm{F} \Delta \mathrm{Ct} 7$ and $\mathrm{HeV}$ F $\Delta \mathrm{Ct} 1$ through $\mathrm{F} \Delta \mathrm{Ct} 7$ (Figure $4 \mathrm{~A}$ and $4 \mathrm{~B}$ ). All constructs were sequenced confirmed.

Attachment (G) glycoprotein constructs and mutagenesis Full-length cDNA clones of the $\mathrm{NiV}$ and $\mathrm{HeV}$ G glycoprotein genes [30,41] each including the Kozak consensus sequence (CCACC) appended upstream of the initial ATG [77] were subcloned into pCAGGs, generating the NiV G-pCAGGs and HeV G-pCAGGs expression vectors. The splice site mutations (Figure $1 \mathrm{C}$ ) of the $\mathrm{HeV}$ $\mathrm{G}$ gene were generated by site-directed mutagenesis using the QuickChange II Site-directed Mutagenesis Kit and QuickChange Multi Site-directed Mutagenesis Kit (Stratagene, Cedar Creek, TX). The template for the mutagenesis reactions was a $\mathrm{HeV} \mathrm{G}$ clone in the TOPO plasmid (Invitrogen Corp., Carlsbad, CA). For the first donor splice site D1 at nucleotide position 1749, the TTG codon for leucine was changed to CTT. The other redundant codons for leucine are CTG, CTA, CTC, and TTA, but these were not effective in removing the predicted splice site. For the second donor splice site D2 at nucleotide position 1858, the AGT codon for serine was changed to TCG. For the third donor splice site D3 at nucleotide position 2259, the GGG codon for glycine was changed to GGT. All PCR products were gel purified and cloned into TOPO and subsequently subcloned into pCAGGs. All mutation-containing constructs were sequence verified.

\section{Cell surface biotinylation}

HeLa-USU cells grown in $T 25 \mathrm{~cm}^{2}$ flasks were transfected with the pCAGGs expression constructs of $\mathrm{NiV}$ and $\mathrm{HeV} F$ alone or along with their partner G glycoprotein constructs with Fugene reagent (Roche Diagnostics Corp, IN) for 36 hrs. Following expression, cells were rinsed three times with ice-cold phosphate buffered saline (PBS) and cell surface proteins were biotinylated using $0.25 \mathrm{mg} / \mathrm{ml}$ EZ-Link NHS-Biotin (Pierce, Rockford, IL) in PBS for $30 \mathrm{~min}$ at $4^{\circ} \mathrm{C}$ [50]. The reaction was quenched by washing the cell monolayer three times with ice-cold PBS before harvesting cells and preparation of cell lysates. Cells were lysed in $100 \mathrm{mM}$ Tris- $\mathrm{HCl}$ (pH 8.0), $100 \mathrm{mM} \mathrm{NaCl}, 1 \%$ Triton X-100 and protease inhibitor at $4^{\circ} \mathrm{C}$ for $30 \mathrm{~min}$ and one-half of each lysate was incubated with $100 \mu \mathrm{l}$ of $20 \% \mathrm{vol} / \mathrm{vol}$ solution of Agarose-Avidin D beads (Vector Laboratories, Inc., Burlingame, CA) in IP buffer $(0.14 \mathrm{M} \mathrm{NaCl}$, $0.1 \mathrm{M}$ Tris, and $0.1 \%$ Triton) at $4{ }^{\circ} \mathrm{C}$ and rotated overnight. Beads were washed twice with lysis buffer followed by one wash with DOC buffer $(100 \mathrm{mM}$ Tris- $\mathrm{HCl}$ (pH 8.0), $100 \mathrm{mM} \mathrm{NaCl}, 0.1 \%$ sodium deoxycholate, and $0.1 \%$ SDS). Samples were boiled in SDS-PAGE sample buffer with 2-mercaptoethanol, separated on a $4-20 \%$ Tris-Glycine gradient gel (Invitrogen), transferred to nitrocellulose, and probed with a cross-reactive polyclonal mouse antiserum to $\mathrm{HeV} \mathrm{G}$ at a concentration of $1: 25,000$ or a rabbit polyclonal $F_{1}$ specific antiserum at a concentration of 1:25,000.

\section{Cell fusion Assays}

Henipavirus F and G mediated fusion activities were measured using a previously described quantitative viral glycoprotein-mediated cell-cell fusion assay $[30,41,57]$. Briefly, one cell population (effector cells) is infected with a recombinant vaccinia virus expressing the $\mathrm{T} 7$ polymerase (vTF7.3) and the other cell population (target cells) is infected with a vaccinia virus encoding the E. coli lac $Z$ gene $(\beta-\mathrm{Gal})$ gene under control of the T7 promoter (vCB21R). Cell-cell fusion between effector and target cell results in $\beta$-Gal synthesis which can be measured by specific synthetic substrate cleavage. Plasmids encoding $\mathrm{NiV}$ or $\mathrm{HeV} \mathrm{G}$ along with their respective wild-type $\mathrm{F}$ glycoprotein partner or the various truncation mutants of $\mathrm{F}$ were transfected into HeLaUSU cells and allowed to express overnight (effector cell populations). Effector cell populations were also prepared using empty vector, pCAGGs, or $\mathrm{NiV}$ or $\mathrm{HeV} \mathrm{F}$ glycoprotein alone as additional negative controls. The various effector cell populations were infected with vTF7.3 and a fusion permissive 293T target cell population was prepared by infection with vCB21R. Vaccinia virus infections were carried out with a multiplicity of infection of 10, suspended in media and incubated at $31^{\circ} \mathrm{C}$ overnight as previously described[30,41,57]. Cell fusion reactions were conducted with the various cell mixtures in 96 -well plates at $37^{\circ} \mathrm{C}$ with a ratio of envelope glycoprotein-expressing cells to target cells of $1: 1$ using $2 \times 10^{5}$ total cells per well in a total volume of 0.2 $\mathrm{ml}$ per well for $2.5 \mathrm{~h}$. For quantitative analyses, Nonidet P-40 was added $(0.5 \% \mathrm{vol} / \mathrm{vol})$ and aliquots of the cellcell fusion lysates were assayed for $\beta$-Gal at ambient temperature with the substrate chlorophenol red-dgalactopyranoside (Roche Diagnostics Corp, IN, USA). Assays were performed in triplicate, and fusion results were calculated and expressed as rates of $\beta$-Gal activity 
(change in optical density at $570 \mathrm{~nm}$ per minute $\times$ 1,000) in an MRX microplate reader (Dynatech Laboratories, Chantilly, VA).

\section{Preparation of henipavirus envelope glycoprotein pseudotyped lentivirus particles}

Pseudotyped, HIV-1 reporter gene encoding virus stocks were prepared by transfecting $293 \mathrm{~T}$ cells with the reporter gene-encoding backbone plasmids pNL4-3-Luc-E- $\mathrm{R}^{+}$ or pNL4-3-GFP-E- $\mathrm{R}^{+}$along with the henipavirus envelope glycoprotein encoding pCAGGs vectors. $293 \mathrm{~T}$ cells $\left(0.75 \times 10^{6}\right)$ were seeded in a 6 -well flat-bottom collagen I-coated microplate (BD Biosciences, Durham, NC) and transfected with the expression plasmids using the Fugene reagent (Roche Diagnostics Corp, IN). The DNAs of the pNL4-3-Luc-E-R ${ }^{+}$or pNL4-3-GFP-E-R ${ }^{+}$along with the $\mathrm{HeV}$ or NiV F and $\mathrm{G}$ encoding pCAGGs plasmids were mixed in the ratio of 1:0.2:0.8, respectively, and added to $500 \mu \mathrm{l}$ of serum free DMEM and $9 \mu \mathrm{l}$ Fugene. The mixture was incubated at room temperature for $30 \mathrm{~min}$ and then applied to the culture of $293 \mathrm{~T}$ cells. After 3 to $5 \mathrm{hr}$ incubation at $37^{\circ} \mathrm{C}$, transfected cells were washed extensively with DMEM and incubated for additional $24-48 \mathrm{hr}$ with $1 \mathrm{ml}$ of DMEM-10, at $37^{\circ} \mathrm{C}$ in $5 \%$ $\mathrm{CO}_{2}$. The supernatants from virus particle producing cultures were then collected and were clarified by centrifugation for $10 \mathrm{~min}$ at $1500 \mathrm{rpm}$, filtered through low protein binding $0.45 \mu \mathrm{m}$ syringe filter (Millipore, Bedford, MA) and partially purified through $25 \% \mathrm{wt} / \mathrm{vol}$ sucrose in Hepes- $\mathrm{NaCl}$ buffer by centrifugation at $36000 \times g$ at $4^{\circ} \mathrm{C}$ for $2.5 \mathrm{hr}$. The pellet was resuspended overnight at $4^{\circ} \mathrm{C}$ in $10 \%$ sucrose in Hepes- $\mathrm{NaCl}$ buffer and used immediately or stored at $-80^{\circ} \mathrm{C}$.

\section{Incorporation of henipavirus envelope glycoproteins in the pseudotyped lentivirus particles}

To measure the incorporation of the henipavirus $\mathrm{F}$ and G glycoproteins into pseudotyped HIV-1 particles, sucrose cushion purified particles were lysed in buffer containing $100 \mathrm{mM}$ Tris- $\mathrm{HCl}$ (pH 8.0), $100 \mathrm{mM} \mathrm{NaCl}$, $2 \%$ Triton $\mathrm{X}-100$ and protease inhibitors at $4{ }^{\circ} \mathrm{C}$ for 30 min. Samples were boiled in SDS-PAGE sample buffer with 2-mercaptoethanol and separated on a 4-20\% TrisGlycine gradient gels (Invitrogen), transferred to nitrocellulose, and probed with a cross-reactive polyclonal mouse antiserum to $\mathrm{HeV} \mathrm{G}$ at a concentration of $1: 25,000$ or a rabbit polyclonal $F_{1}$ specific antiserum at a concentration of 1:25,000.

\section{Pseudotyped virus infection assays}

Receptor positive cell lines, seeded into 48-well plates at a concentration of $10^{5}$ cells per well, were infected (transduced) with pseudovirus, normalized for p24 antigen content using the HIV-1 p24 EIA Kit from
Beckman-Coulter, and all infection experiments were carried out in triplicate wells. No DEAE-Dextran or polybrene was used to facilitate fusion/infection by the pseudovirions. After infecting for 2.5-3 hr, the cells were washed and incubated for additional 48-72 hr. For luciferase encoding particles, cells were lysed with $0.5 \%$ Triton X-100 in PBS and a $50 \mu \mathrm{l}$ aliquot of the lysate was assayed for luciferase activity using luciferase substrate (Promega, Madison, WI) on a Mikrowin luminometer (Berthold Technologies Model: Centro LB 960). For the GFP-encoding particles, the efficiency of infection was evaluated by counting the number of green cells $48 \mathrm{~h}$ post-infection using Olympus IX81 fluorescent microscope.

For inhibition of pseudotyped virus infection assays, pNL4-3-Luc-E- ${ }^{+}$based virus particles pseudotyped with full-length $\mathrm{NiV}$ or $\mathrm{HeV} F$ and $\mathrm{G}$ envelope glycoproteins were pre-incubated with $2 \mu$ g each of $\mathrm{NiVsG}$, mAb102.4 IgG, NiV-FC2 (fusion inhibiting) or Sc-NiVFC2 (scrambled control peptide), recombinant soluble murine ephrin-B2 (rmEFN-B2/Fc) or recombinant soluble human ephrin-B3 (rhEFN-B3/Fc) at $4^{\circ} \mathrm{C}$ for $1 \mathrm{hr}$. Receptor positive $293 \mathrm{~T}$ cells, seeded into 48 -well plates $\left(10^{5}\right.$ cells per well) were then infected with the various pre-treated pseudotyped virus particles and processed as above. All infection experiments were performed in triplicate.

\section{Additional material}

Additional file 1: Splice site prediction in the pre-mRNA derived from the $\mathrm{HeV}$ G gene as cloned in pCAGGs. EMBL-EBI Splice site prediction software http://www.ebi.ac.uk/asd-srv/wb.cgi?method=7 was used to check for the presence of splice donor sites in the $G$ glycoprotein constructs cloned in the pCAGGs vector. Splice acceptor site present in the intron at position 1670-71 is shown on the left for all the constructs. On the right is shown the predicted splice donor site.

\section{Acknowledgements \\ The views expressed in the manuscript are solely those of the authors, and they do not represent official views or opinions of the Department of Defense or The Uniformed Services University of the Health Science. This work was supported by $\mathrm{NIH}$ grant Al054715 to C.C.B. Portions of this work were originally presented at the 2006 Keystone Symposia: Cell Biology of Virus Entry, Santa Fe, New Mexico.}

\section{Authors' contributions}

DK contributed to the development of the Henipavirus pseudovirus assay, designed and constructed all the expression constructs and carried out the experiments, identified the alternative splicing process in the original Hendra virus $\mathrm{G}$ encoding PCAGGs plasmid clone, interpreted data, and wrote the first drafts of the figures and manuscript. CCB conceived of and contributed to the development of the Henipavirus pseudovirus assay provided overall supervision and financial support and wrote and prepared the final versions of the figures and manuscript. Both authors read and approved the final manuscript.

Competing interests

The authors declare that they have no competing interests. 
Received: 9 September 2010 Accepted: 12 November 2010 Published: 12 November 2010

\section{References}

1. Eaton BT, Broder CC, Middleton D, Wang LF: Hendra and Nipah viruses: different and dangerous. Nat Rev Microbiol 2006, 4:23-35.

2. Bishop KA, Broder CC: Hendra and Nipah: Lethal Zoonotic Paramyxoviruses. In Emerging Infections. Edited by: Scheld WM, Hammer SM, Hughes JM. Washington, D.C.: American Society for Microbiology; 2008:155-187.

3. Wang L, Harcourt BH, Yu M, Tamin A, Rota PA, Bellini WJ, Eaton BT: Molecular biology of Hendra and Nipah viruses. Microbes Infect 2001, 3:279-287.

4. Eaton BT, Mackenzie JS, Wang LF: Henipaviruses. In Fields Virology. Volume 2. 5 edition. Edited by: Knipe DM, Howley PM. Philadelphia: Lippincott Williams 2007:1587-1600

5. Li Y, Wang J, Hickey AC, Zhang Y, Wu Y, Zhang H, Yuan J, Han Z, McEachern J, Broder CC, et al: Antibodies to Nipah or Nipah-like viruses in bats, China. Emerg Infect Dis 2008, 14:1974-1976.

6. Hayman DT, Suu-Ire R, Breed AC, McEachern JA, Wang L, Wood JL, Cunningham AA: Evidence of henipavirus infection in West African fruit bats. PLOS ONE 2008, 3:e2739.

7. Anonymous: Hendra virus, human, equine - Australia (05): Queensland. Pro-med International Society for Infectious Diseases; 2009 [http://www. promedmail.org], September 10, archive no 20090910.3189.

8. Anonymous: Hendra virus, equine - Australia (03): (QL) human exp. ProMED International Society for Infectious Diseases; 2010 [http://www. promedmail.org], May 22, archive no 20100522.1699.

9. Playford EG, McCall B, Smith G, Slinko V, Allen G, Smith I, Moore F, Taylor C, Kung $Y H$, Field $H$ : Human Hendra virus encephalitis associated with equine outbreak, Australia, 2008. Emerg Infect Dis 2010, 16:219-223.

10. Anonymous: Nipah Virus, Fatal - Bangladesh (Dhaka). Pro-Med International Society for Infectious Diseases; 2008 [http://www.promedmail. org], March 11, 2008, archive no 20080311.0979.

11. Anonymous: Nipah virus, fatal - Bangladesh: (Faridpur). Pro-MED International Society for Infectious Diseases; 2010 [http://www.promedmail. org], January 22, 2010, archive no 20100122.0250.

12. Gurley ES, Montgomery JM, Hossain MJ, Bell M, Azad AK, Islam MR, Molla MA, Carroll DS, Ksiazek TG, Rota PA, et al: Person-to-person transmission of Nipah virus in a Bangladeshi community. Emerg Infect Dis 2007, 13:1031-1037.

13. Harit AK, Ichhpujani RL, Gupta S, Gill KS, Lal S, Ganguly NK, Agarwal SP: Nipah/Hendra virus outbreak in Siliguri, West Bengal, India in 2001. Indian J Med Res 2006, 123:553-560.

14. Luby SP, Rahman M, Hossain MJ, Blum LS, Husain MM, Gurley E, Khan R, Ahmed BN, Rahman S, Nahar N, et al: Foodborne transmission of Nipah virus, Bangladesh. Emerg Infect Dis 2006, 12:1888-1894

15. Bossart KN, Zhu Z, Middleton D, Klippel J, Crameri G, Bingham J, McEachern JA, Green D, Hancock TJ, Chan YP, et al: A neutralizing human monoclonal antibody protects against lethal disease in a new ferret model of acute nipah virus infection. PLoS Pathog 2009, 5:e1000642.

16. Marianneau P, Guillaume V, Wong T, Badmanathan M, Looi RY, Murri S, Loth $\mathrm{P}$, Tordo N, Wild F, Horvat B, Contamin H: Experimental infection of squirrel monkeys with nipah virus. Emerg Infect Dis 2010, 16:507-510.

17. Geisbert TW, Daddario-DiCaprio KM, Hickey AC, Smith MA, Chan YP, Wang LF, Mattapallil JJ, Geisbert JB, Bossart KN, Broder CC: Development of an acute and highly pathogenic nonhuman primate model of Nipah virus infection. PLOS One 2010, 5:e10690.

18. Rockx B, Bossart KN, Feldmann F, Geisbert JB, Hickey AC, Brining D, Callison J, Safronetz D, Marzi A, Kercher $L$, et al: A novel model of lethal Hendra virus infection in African green monkeys and the effectiveness of ribavirin treatment. J Virol 2010, 84:9831-9839.

19. Bossart KN, Broder CC: Developments towards effective treatments for Nipah and Hendra virus infection. Expert Rev Anti Infect Ther 2006, 4:43-55.

20. Bonaparte MI, Dimitrov AS, Bossart KN, Crameri G, Mungall BA, Bishop KA, Choudhry V, Dimitrov DS, Wang LF, Eaton BT, Broder CC: Ephrin-B2 ligand is a functional receptor for Hendra virus and Nipah virus. Proc Natl Acad Sci USA 2005, 102:10652-10657.

21. Negrete $\mathrm{OA}$, Levroney EL, Aguilar HC, Bertolotti-Ciarlet A, Nazarian R Tajyar S, Lee B: EphrinB2 is the entry receptor for Nipah virus, an emergent deadly paramyxovirus. Nature 2005, 436:401-405.
22. Negrete $\mathrm{OA}$, Wolf MC, Aguilar $\mathrm{HC}$, Enterlein $\mathrm{S}$, Wang W, Muhlberger $\mathrm{E}_{1}$ Su SV, Bertolotti-Ciarlet A, Flick R, Lee B: Two key residues in ephrinB3 are critical for its use as an alternative receptor for Nipah virus. PLOS Pathog 2006, 2:e7.

23. Bishop KA, Stantchev TS, Hickey AC, Khetawat D, Bossart KN, Krasnoperov V Gill P, Feng YR, Wang L, Eaton BT, et al: Identification of hendra virus $\mathrm{g}$ glycoprotein residues that are critical for receptor binding. J Virol 2007, 81:5893-5901.

24. Himanen JP, Saha N, Nikolov DB: Cell-cell signaling via Eph receptors and ephrins. Curr Opin Cell Biol 2007, 19:534-542.

25. Pasquale EB: Eph receptor signalling casts a wide net on cell behaviour. Nat Rev Mol Cell Biol 2005, 6:462-475.

26. Bossart KN, Broder CC: Paramyxovirus Entry. In Viral Entry into Host Cells. Edited by: Pöhlmann S, Simmons G. Austin, TX Landes Bioscience; 2009:

27. Pager $C T$, Dutch RE: Cathepsin $L$ is involved in proteolytic processing of the hendra virus fusion protein. J Virol 2005, 79:12714-12720.

28. Bossart KN, Crameri G, Dimitrov AS, Mungall BA, Feng YR, Patch JR, Choudhary A, Wang LF, Eaton BT, Broder CC: Receptor binding, fusion inhibition, and induction of cross-reactive neutralizing antibodies by a soluble g glycoprotein of hendra virus. J Virol 2005, 79:6690-6702.

29. Bossart KN, McEachern JA, Hickey AC, Choudhry V, Dimitrov DS, Eaton BT, Wang LF: Neutralization assays for differential henipavirus serology using Bio-Plex Protein Array Systems. J Virol Methods 2007, 142:29-40.

30. Bossart KN, Wang LF, Flora MN, Chua KB, Lam SK, Eaton BT, Broder CC: Membrane fusion tropism and heterotypic functional activities of the nipah virus and hendra virus envelope glycoproteins. J Virol 2002 76:11186-11198.

31. Xu K, Rajashankar KR, Chan YP, Himanen JP, Broder CC, Nikolov DB: Host cell recognition by the henipaviruses: crystal structures of the Nipah $G$ attachment glycoprotein and its complex with ephrin-B3. Proc Natl Acad Sci USA 2008, 105:9953-9958.

32. Bowden TA, Aricescu AR, Gilbert RJ, Grimes JM, Jones EY, Stuart DI: Structural basis of Nipah and Hendra virus attachment to their cellsurface receptor ephrin-B2. Nat Struct Mol Biol 2008, 15:567-572.

33. Kaku Y, Noguchi A, Marsh GA, McEachern JA, Okutani A, Hotta K, Bazartseren B, Fukushi S, Broder CC, Yamada A, et al: A neutralization test for specific detection of Nipah virus antibodies using pseudotyped vesicular stomatitis virus expressing green fluorescent protein. J Virol Methods 2009, 160:7-13.

34. Baum C, Schambach A, Bohne J, Galla M: Retrovirus vectors: toward the plentivirus? Mol Ther 2006, 13:1050-1063.

35. Han DP, Kim HG, Kim YB, Poon LL, Cho MW: Development of a safe neutralization assay for SARS-CoV and characterization of S-glycoprotein. Virology 2004, 326:140-149.

36. Chan SY, Speck RF, Ma MC, Goldsmith MA: Distinct mechanisms of entry by envelope glycoproteins of Marburg and Ebola (Zaire) viruses. J Virol 2000, 74:4933-4937.

37. Wang W, Butler EN, Veguilla V, Vassell R, Thomas JT, Moos M Jr, Ye Z, Hancock K, Weiss CD: Establishment of retroviral pseudotypes with influenza hemagglutinins from $\mathrm{H} 1, \mathrm{H} 3$, and $\mathrm{H} 5$ subtypes for sensitive and specific detection of neutralizing antibodies. J Virol Methods 2008 153:111-119.

38. Kobayashi M, lida A, Ueda Y, Hasegawa M: Pseudotyped Lentivirus Vectors Derived from Simian Immunodeficiency Virus SIVagm with Envelope Glycoproteins from Paramyxovirus. J Virol 2003, 77:2607-2614.

39. Bossart KN, Mungall BA, Crameri G, Wang LF, Eaton BT, Broder CC: Inhibition of Henipavirus fusion and infection by heptad-derived peptides of the Nipah virus fusion glycoprotein. Virol J 2005, 2:57.

40. Connor Rl, Chen BK, Choe S, Landau NR: Vpr is required for efficient replication of human immunodeficiency virus type-1 in mononuclear phagocytes. Virology 1995, 206:935-944

41. Bossart KN, Wang LF, Eaton BT, Broder CC: Functional expression and membrane fusion tropism of the envelope glycoproteins of Hendra virus. Virology 2001, 290:121-135.

42. Niwa H, Yamamura K, Miyazaki J: Efficient selection for high-expression transfectants with a novel eukaryotic vector. Gene 1991, 108:193-199.

43. Kilby JM, Hopkins S, Venetta TM, DiMassimo B, Cloud GA, Lee JY,

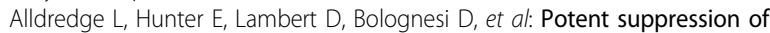
HIV-1 replication in humans by T-20, a peptide inhibitor of gp41mediated virus entry. Nat Med 1998, 4:1302-1307. 
44. Kilby JM, Lalezari JP, Eron JJ, Carlson M, Cohen C, Arduino RC, Goodgame JC, Gallant JE, Volberding P, Murphy RL, et al: The safety, plasma pharmacokinetics, and antiviral activity of subcutaneous enfuvirtide (T-20), a peptide inhibitor of gp41-mediated virus fusion, in HIV-infected adults.PG - 685-93. AIDS Res Hum Retroviruses 2002, 18:685-693.

45. Zhu Z, Dimitrov AS, Bossart KN, Crameri G, Bishop KA, Choudhry V, Mungall BA, Feng YR, Choudhary A, Zhang MY, et al: Potent neutralization of Hendra and Nipah viruses by human monoclonal antibodies. J Virol 2006, 80:891-899.

46. Zhu Z, Bossart KN, Bishop KA, Crameri G, Dimitrov AS, McEachern JA, Feng Y, Middleton D, Wang LF, Broder CC, Dimitrov DS: Exceptionally potent cross-reactive neutralization of Nipah and Hendra viruses by a human monoclonal antibody. J Infect Dis 2008, 197:846-853.

47. Hohne M, Thaler S, Dudda JC, Groner B, Schnierle BS: Truncation of the human immunodeficiency virus-type- 2 envelope glycoprotein allows efficient pseudotyping of murine leukemia virus retroviral vector particles. Virology 1999, 261:70-78.

48. Indraccolo S, Minuzzo S, Feroli F, Mammano F, Calderazzo F, ChiecoBianchi L, Amadori A: Pseudotyping of Moloney leukemia virus-based retroviral vectors with simian immunodeficiency virus envelope leads to targeted infection of human CD4+ lymphoid cells. Gene Ther 1998, 5:209-217

49. Mammano F, Salvatori F, Indraccolo S, De Rossi A, Chieco-Bianchi L, Gottlinger HG: Truncation of the human immunodeficiency virus type 1 envelope glycoprotein allows efficient pseudotyping of Moloney murine leukemia virus particles and gene transfer into CD4+ cells. J Virol 1997, 71:3341-3345.

50. Bishop KA, Hickey AC, Khetawat D, Patch JR, Bossart KN, Zhu Z, Wang LF, Dimitrov DS, Broder CC: Residues in the stalk domain of the hendra virus g glycoprotein modulate conformational changes associated with receptor binding. J Virol 2008, 82:11398-11409.

51. Bonifacino JS, Traub LM: Signals for sorting of transmembrane proteins to endosomes and lysosomes. Annu Rev Biochem 2003, 72:395-447.

52. Weise C, Erbar S, Lamp B, Vogt C, Diederich S, Maisner A: Tyrosine residues in the cytoplasmic domains affect sorting and fusion activity of the Nipah virus glycoproteins in polarized epithelial cells. J Virol 2010, 84:7634-7641.

53. Meulendyke KA, Wurth MA, McCann RO, Dutch RE: Endocytosis plays a critical role in proteolytic processing of the hendra virus fusion protein. $J$ Virol 2005, 79:12643-12649.

54. Gardner AE, Dutch RE: A conserved region in the $F(2)$ subunit of paramyxovirus fusion proteins is involved in fusion regulation. $J$ Virol 2007, 81:8303-8314.

55. Gardner AE, Martin KL, Dutch RE: A conserved region between the heptad repeats of paramyxovirus fusion proteins is critical for proper $F$ protein folding. Biochemistry 2007, 46:5094-5105.

56. Nussbaum O, Broder CC, Berger EA: Fusogenic mechanisms of envelopedvirus glycoproteins analyzed by a novel recombinant vaccinia virusbased assay quantitating cell fusion-dependent reporter gene activation. J Virol 1994, 68:5411-5422.

57. Bossart KN, Broder CC: Viral glycoprotein-mediated cell fusion assays using vaccinia virus vectors. Methods Mol Biol 2004, 269:309-332.

58. Lamb RA, Jardetzky TS: Structural basis of viral invasion: lessons from paramyxovirus F. Curr Opin Struct Biol 2007, 17:427-436.

59. Hughson FM: Enveloped viruses: a common mode of membrane fusion? Curr Biol 1997, 7:R565-569.

60. Singh $M$, Berger B, Kim PS: LearnCoil-VMF: computational evidence for coiled-coil-like motifs in many viral membrane-fusion proteins. $J \mathrm{Mol}$ Biol 1999, 290:1031-1041

61. Joshi $S B$, Dutch RE, Lamb RA: A core trimer of the paramyxovirus fusion protein: parallels to influenza virus hemagglutinin and HIV-1 gp41. Virology 1998, 248:20-34.

62. Lambert DM, Barney S, Lambert AL, Guthrie K, Medinas R, Davis DE, Bucy T, Erickson J, Merutka G, Petteway SR Jr: Peptides from conserved regions of paramyxovirus fusion (F) proteins are potent inhibitors of viral fusion. Proc Natl Acad Sci USA 1996, 93:2186-2191.

63. Rapaport D, Ovadia M, Shai Y: A synthetic peptide corresponding to a conserved heptad repeat domain is a potent inhibitor of Sendai viruscell fusion: an emerging similarity with functional domains of other viruses. Embo J 1995, 14:5524-5531.
64. Young JK, Li D, Abramowitz MC, Morrison TG: Interaction of peptides with sequences from the Newcastle disease virus fusion protein heptad repeat regions. J Virol 1999, 73:5945-5956.

65. Young JK, Hicks RP, Wright GE, Morrison TG: Analysis of a peptide inhibitor of paramyxovirus (NDV) fusion using biological assays, NMR, and molecular modeling. Virology 1997, 238:291-304.

66. Wild TF, Buckland R: Inhibition of measles virus infection and fusion with peptides corresponding to the leucine zipper region of the fusion protein. J Gen Virol 1997, 78(Pt 1):107-111.

67. Mulligan MJ, Yamshchikov GV, Ritter GD Jr, Gao F, Jin MJ, Nail CD, Spies CP, Hahn BH, Compans RW: Cytoplasmic domain truncation enhances fusion activity by the exterior glycoprotein complex of human immunodeficiency virus type 2 in selected cell types. J Virol 1992, 66:3971-3975.

68. Ritter GD, Mulligan MJ, Lydy SL, Compans RW: Cell fusion activity of the simian immunodeficiency virus envelope protein is modulated by the intracytoplasmic domain. Virology 1993, 197:255-264.

69. Ragheb JA, Anderson WF: Uncoupled expression of Moloney murine leukemia virus envelope polypeptides SU and TM: a functional analysis of the role of TM domains in viral entry. J Virol 1994, 68:3207-3219.

70. Rein A, Mirro J, Haynes JG, Ernst SM, Nagashima K: Function of the cytoplasmic domain of a retroviral transmembrane protein: $15 \mathrm{E}-\mathrm{p} 2 \mathrm{E}$ cleavage activates the membrane fusion capability of the murine leukemia virus Env protein. J Virol 1994, 68:1773-1781.

71. Dutch RE, Lamb RA: Deletion of the cytoplasmic tail of the fusion protein of the paramyxovirus simian virus 5 affects fusion pore enlargement. $J$ Virol 2001, 75:5363-5369.

72. Sergel T, Morrison TG: Mutations in the cytoplasmic domain of the fusion glycoprotein of Newcastle disease virus depress syncytia formation. Virology 1995, 210:264-272.

73. Yao Q, Compans RW: Differences in the role of the cytoplasmic domain of human parainfluenza virus fusion proteins. J Virol 1995, 69:7045-7053.

74. Pernet $O$, Pohl C, Ainouze $M$, Kweder $H$, Buckland R: Nipah virus entry can occur by macropinocytosis. Virology 2009, 395:298-311.

75. Deng H, Liu R, Ellmeier W, Choe S, Unutmaz D, Burkhart M, Di Marzio P, Marmon S, Sutton RE, Hill CM, et al: Identification of a major co-receptor for primary isolates of HIV-1 [see comments]. Nature 1996, 381:661-666.

76. Mungall BA, Middleton D, Crameri G, Bingham J, Halpin K, Russell G, Green D, McEachern J, Pritchard LI, Eaton BT, et al: Feline model of acute nipah virus infection and protection with a soluble glycoprotein-based subunit vaccine. J Virol 2006, 80:12293-12302.

77. Kozak M: An analysis of $5^{\prime}$-noncoding sequences from 699 vertebrate messenger RNAs. Nucleic Acids Res 1987, 15:8125-8148.

doi:10.1186/1743-422X-7-312

Cite this article as: Khetawat and Broder: A Functional Henipavirus Envelope Glycoprotein Pseudotyped Lentivirus Assay System. Virology Journal 2010 7:312.

\section{Submit your next manuscript to BioMed Central and take full advantage of:}

- Convenient online submission

- Thorough peer review

- No space constraints or color figure charges

- Immediate publication on acceptance

- Inclusion in PubMed, CAS, Scopus and Google Scholar

- Research which is freely available for redistribution

Submit your manuscript at www.biomedcentral.com/submit
C Biomed Central 